\title{
Influence of Beet necrotic yellow vein virus and Freezing Temperatures on Sugar Beet Roots in Storage
}

Carl A. Strausbaugh ${ }^{\dagger}$ and Imad A. Eujayl, United States Department of Agriculture-Agricultural Research Service Northwest Irrigation and Soils Research Laboratory, Kimberly, ID 83341

\begin{abstract}
Rhizomania caused by Beet necrotic yellow vein virus (BNYVV) is a yield-limiting sugar beet disease that was observed to influence root resistance to freezing in storage. Thus, studies were conducted to gain a better understanding of the influence of BNYVV and freezing on sugar beet roots to improve pile management decisions. Roots from five commercial sugar beet cultivars (one susceptible and four resistant to BNYVV) were produced in fields under high and trace levels of rhizomania pressure and subjected to storage using five temperature regimes ranging from 0 to $-4.4^{\circ} \mathrm{C}$ for $24 \mathrm{~h}$. After cold treatment, eight-root samples were stored in a commercial indoor storage building (set point $1.1^{\circ} \mathrm{C}$ ) for 50 days in 2014 and 57 days in 2015. Internal root temperature, frozen and discolored tissue, and moisture and sucrose loss were evaluated. The air temperature at $0,-1.1$, and $-2.2^{\circ} \mathrm{C}$ matched internal root temperature but internal root remained near $-2.2^{\circ} \mathrm{C}$ when air

temperature was dropped to -3.3 and $-4.4^{\circ} \mathrm{C}$. In a susceptible cultivar produced under high rhizomania pressure, the percentage of frozen tissue increased $(P<0.0001)$ from an average of 0 to $7 \%$ at $0,-1.1$, and $-2.2^{\circ} \mathrm{C}$ up to 16 to $63 \%$ at $-3.3^{\circ} \mathrm{C}$ and 63 to $90 \%$ at $-4.4^{\circ} \mathrm{C}$, depending on year. Roots from the susceptible cultivar produced under low rhizomania pressure and those from the resistant cultivars from both fields only had elevated $(P \leq 0.05)$ frozen tissue at $-4.4^{\circ} \mathrm{C}$ in 15 of 18 cultivar-year combinations. Frozen tissue was related to discolored tissue $\left(r^{2}=\right.$ $0.91)$, weight loss $\left(r^{2}=0.12\right.$ to 0.28$)$, and sucrose reduction $\left(r^{2}=0.69\right.$ to 0.74$)$. Consequently, BNYVV will not only lead to yield and sucrose loss in susceptible sugar beet cultivars but also to more frozen root tissue as temperatures drop below $-2.2^{\circ} \mathrm{C}$. Based on these observations, the air used to cool roots in nonfrozen sugar beet piles throughout the winter should not drop below $-2.2^{\circ} \mathrm{C}$ to maximize sucrose retention.
\end{abstract}

Rhizomania caused by Beet necrotic yellow vein virus (BNYVV) and vectored by Polymyxa betae is a destructive disease of sugar beet (Beta vulgaris L.) that is widespread in sugar beet production areas worldwide (Liu et al. 2005; Rush 2003; Rush et al. 2006; Ward et al. 2007). Rhizomania is largely controlled through host resistance (Liu et al. 2005; Rush 2003; Rush et al. 2006). Initially, only the $R z 1$ rhizomania resistance gene was utilized in commercial sugar beet cultivars, but resistance-breaking strains began to appear (Acosta-Leal et al. 2008; Bornemann and Varrelmann 2011; Liu and Lewellen 2007; Liu et al. 2005). Fortunately, the resistance-breaking strains have been less fit than wild-type strains of BNYVV; therefore, they have not become a dominant population in the field (Bornemann and Varrelmann, 2013). However, individual plants with obvious rhizomania foliar symptoms (commonly referred to as blinkers) can frequently be observed in Idaho fields if the $R z 1$ or $R z 2$ genes are used independently (Panella and Strausbaugh 2017). Now $R z 1$ and $R z 2$ are commonly used together in commercial cultivars and additional resistance genes and alleles have been discovered (Biancardi et al. 2002; Gidner et al. 2005; Grimmer et al. 2007, 2008; Scholten et al. 1999). Combining different genes for resistance alleviates concerns with resistance breaking down in commercial sugar beet cultivars.

Rhizomania not only influences yield but also can lead to a negative influence on storability (Campbell et al. 2008; Strausbaugh et al. $2008 \mathrm{~b}, 2009,2015)$. The majority of sugar beet roots are stored prior to factory processing (Bugbee 1993). In Idaho, approximately twothirds of the crop is stored, with some roots stored for over 150 days

${ }^{\dagger}$ Corresponding author: C. A. Strausbaugh;

E-mail: carl.strausbaugh@ars.usda.gov

Mention of trade names or commercial products in this article is solely for the purpose of providing scientific information and does not imply recommendation or endorsement by the U.S. Department of Agriculture. The USDA is an equal opportunity provider and employer.

Accepted for publication 7 December 2017.

This article is in the public domain and not copyrightable. It may be freely reprinted with customary crediting of the source. The American Phytopathological Society, 2018.
(Huff 2013; Peterson et al. 1984; Strausbaugh et al. 2009, 2015). For example, some Idaho sugar beet roots that were harvested in October 2016 were not processed until mid-April 2017. Idaho ranks second in production in the United States (National Agriculture Statistics Service); therefore, a significant number of roots are held under ambient conditions in Idaho as well as in Colorado, Montana, Nebraska, Wyoming, and Michigan. When roots are held under ambient conditions, root deterioration and sucrose loss can result from less than ideal weather conditions (both temperature and moisture), microbial growth (particularly where topping, wounding, and bruising occurred), and the accumulation of impurities that impair factory processing (Bugbee 1982, 1993; Strausbaugh et al. 2008b, 2011; Wyse 1978). Additional challenges for successful storage can result from roots being subjected to diseases in the field, including rhizomania (Campbell and Klotz 2006; Campbell et al. 2008, 2011; Klotz and Campbell 2009; Smith and Ruppel 1971; Strausbaugh et al. 2008a,b, 2011).

When storing sugar beet roots under ambient conditions, millions of dollars can be lost in storage (Bugbee 1982; Bugbee and Cole 1976; Huff 2013; Van Driessche 2012). This is particularly true when periods of cold temperature that partially freeze outdoor piles are followed by warmer conditions that thaw frozen tissue. Roots in the outer meter of piles and around ventilation tubes freeze more commonly but, occasionally, prolonged cold periods will freeze roots deeper in the piles. Sugar companies try to alleviate losses by stripping the frozen roots from the outside of piles before they thaw but this is not always done in time to avoid losses, particularly if piles are frozen more than a meter deep (Van Eerd et al. 2012). Consequently, a better understanding of the influence of freezing temperatures on sugar roots in piles could prove helpful with pile management decisions. Observations during past studies (Strausbaugh et al. 2008b) suggested that roots susceptible to BNYVV may be more susceptible to freezing. Therefore, studies were conducted to investigate the influence of BNYVV on the ability of sugar roots to resist freezing temperatures in an effort to more fully understand the impact of BNYVV and allow for improved management options.

\section{Materials and Methods}

Storage study: 2014. Four commercial sugar beet cultivars with resistance to BNYVV-B-7 (Rz1rz2), B-43 (Rz1rz2), B-46 (Rz1Rz2), and B-58 $(R z 1 R z 2)$ - were evaluated for their response to freeze 
damage at five temperatures $\left(0,-1.1,-2.2 .-3.3\right.$, and $-4.4^{\circ} \mathrm{C}$; equivalent to $32,30,28,26$, and $24^{\circ} \mathrm{F}$ ). A susceptible sugar beet cultivar, B-54 $(r z 1 r z 2)$, was also included in the study. For more information on these cultivars, the source of the seed, Betaseed Inc. (Kimberly, ID), can be contacted. Seed of these five cultivars was planted on 22 April at a density of 352,272 seed/ha in fields with a high level (98 to 100\% of the plants from the susceptible cultivar exhibited symptoms [high field]) and trace level (less than $1 \%$ incidence of symptoms with the susceptible cultivar [trace field]) of rhizomania to provide a source of roots. Plants from cultivars with only one gene for resistance had an occasional blinker (less than $1 \%$ of plants) in the high field and no symptoms in the trace field. Plants with two BNYVV resistance genes exhibited no symptoms regardless of field. The fields had Portneuf silt loam soil and were located in Twin Falls County on the United States Department of Agriculture-Agricultural Research Service North Farm $\left(42^{\circ} 33^{\prime} 12.65^{\prime \prime} \mathrm{N}\right.$ $114^{\circ} 21^{\prime} 23.15^{\prime \prime} \mathrm{W}$; elevation $1,188 \mathrm{~m}$ ) near Kimberly, ID. The fields had been in barley the previous year and were disked and plowed in fall 2013. Fertilizer ( $\mathrm{N}$ at $100.8 \mathrm{~kg} / \mathrm{ha}$ and $\mathrm{P}_{2} \mathrm{O}_{5}$ at $123.3 \mathrm{~kg} / \mathrm{ha}$ ) was applied on 11 April and incorporated with a roller harrow. The fields were managed using standard cultural practices outlined in the 2014 sugar beet grower's guide book (Amalgamated Sugar Co. LLC, Boise, ID). The plants were thinned to a density of 117,424 plants/ha on 31 May. On 1 October 2014, plants were mechanically topped and harvested with a two-row harvester. In total, 240 roots for each cultivar-field combination were collected and divided into eight-root samples. Samples were contained in polyethylene mesh onion bags (Idaho Package Company, Idaho Falls, ID). Six eight-root samples were used to establish six replications for each of the five temperatures (five cultivars by five temperatures with six replications by two fields $=300$ samples). Six additional samples from each field collected from plants adjacent to those used in the freeze study were analyzed at the sugar tare laboratory (Amalgamated Sugar Co. LLC, Paul, ID) to establish percent sucrose at harvest. The 300 eight-beet samples were placed on shelves in a refrigerated shipping container (frequently called reefer units; Thermo King, Minneapolis, MN) set to a constant $0^{\circ} \mathrm{C}$ and arranged in a completely randomized block design, with six replications blocked by shelf. The storage temperature was recorded at 1-h intervals using Hobo temperature sensors (Model H08001-02; Onset Computer Corp., Bourne, MA) located among root samples. To track internal root temperature, six additional sugar beet roots were randomly placed throughout the container with Oakton 400-series immersion thermistor 10-cm probes (Oakton Instruments, Vernon Hills, IL) inserted into the center of roots after drilling a 3.175-mm-diameter hole from the top of the root. After allowing the temperature in the roots to stabilize at $0^{\circ} \mathrm{C}$ for 12 days, a temperature series was initiated in which temperature was decreased by $1.1^{\circ} \mathrm{C}$ at $24 \mathrm{~h}$ intervals until $-4.4^{\circ} \mathrm{C}$ was reached. Just before changing the temperature each day, the internal root temperature from the six roots with probes inserted was recorded. After $24 \mathrm{~h}$ at a particular temperature, the 60 root samples for that temperature were removed and placed in a commercial indoor storage facility in Paul, ID (temperature set point: $1.1^{\circ} \mathrm{C}$ ) beginning with the $0^{\circ} \mathrm{C}$ samples on 14 October. Just prior to processing the root samples on 2 December for brei samples (shredded root tissue from the brei saw), roots were weighed, a percent surface area associated with frost (water-soaked tissue) and discolored tissue (water soaked + rotted tissue) was conducted, and 30 root samples with rot were collected for fungal isolation from internal root tissue.

Storage study: 2015. The storage study was repeated in 2015 using the same cultivars and seedlots. Seed was planted on 20 April into adjacent portions of the same fields as the previous year. These portions of the field had been in barley in 2014. The fields were prepared, fertilized, and managed as they had been the previous year. The fields were thinned on 29 May. As noted the previous year, 98 to $100 \%$ of the plants of the BNYVV-susceptible cultivar exhibited symptoms in the high field and less than $1 \%$ incidence was evident in the trace field. Plants from cultivars with only one gene for BNYVV resistance had an occasional blinker (less than $1 \%$ of plants) in the high field and no symptoms in the trace field. Plants with two BNYVV resistance genes exhibited no symptoms regardless of field. The plants were mechanically topped and harvested on 7 October. After allowing the temperature in the roots to stabilize at $0^{\circ} \mathrm{C}$ for 5 days, the temperature series was initiated. After $24 \mathrm{~h}$, the $0^{\circ} \mathrm{C}$ samples were removed and placed in a commercial indoor storage facility in Paul, ID (temperature set point: $1.1^{\circ} \mathrm{C}$ ) on 12 October. The roots were processed for brei on 7 December and 30 root samples were arbitrarily collected for subsequent fungal isolations.

Fungal isolations. To confirm the fungi present in rotted tissue (isolated from leading edge of discolored tissue), isolations were conducted on potato dextrose agar (Becton Dickinson \& Co., Sparks, MD) amended with streptomycin $(200 \mathrm{mg} / \mathrm{liter})$ on the laboratory bench at $22^{\circ} \mathrm{C}$ using techniques described previously (Strausbaugh et al. 2015). Morphocultural characteristics of the cultures were used to establish an identification to genus or species.

Data analysis. The SAS univariate procedure (version 9.4; SAS Institute Inc., Cary, NC) was used to test for normality. Data were also subjected to analysis of variance using the SAS generalized linear models procedure (Proc GLM). Mean comparisons were conducted using Fisher's protected least significant difference $(\alpha=0.05)$. When percent data were all between 0 and $20 \%$, data were square root transformed prior to analysis. However, untransformed means have been presented. Linear regression analyses were conducted using SAS Proc Reg.

\section{Results}

Cold storage temperature. The air temperature in the cold storage unit tracked the set points both years (Fig. 1). The internal root temperature after being at the set point for $24 \mathrm{~h}$ was not different from the set point at $0.0,-1.1$, and $-2.2^{\circ} \mathrm{C}$. However, the internal root temperature remained at $-2.2^{\circ} \mathrm{C}$ after $24 \mathrm{~h}$ at -3.3 and $-4.4^{\circ} \mathrm{C}$ in both years.

Indoor storage temperature. In 2014, the commercial sugar beet storage building took 30 days to reach the temperature set point of $1.1^{\circ} \mathrm{C}$ (Fig. 2). In 2015 , the storage building took 41 days to reach the temperature set point.

Frozen root tissue. In the 2014 and 2015 studies, there were interactions with the frozen tissue data which led us to analyze the data by temperature and field within each cultivar (Table 1). The $-4.4^{\circ} \mathrm{C}$ treatment always ranked the worst for the most frozen root tissue regardless of cultivar and field. In addition, the $-4.4^{\circ} \mathrm{C}$ treatment was significantly $(P=0.0490$ to $P<0.0001)$ worse than all other treatments in 16 of 20 cultivar-field combinations. With the BNYVVsusceptible cultivar B-54, both the -3.3 and $-4.4^{\circ} \mathrm{C}$ treatments had
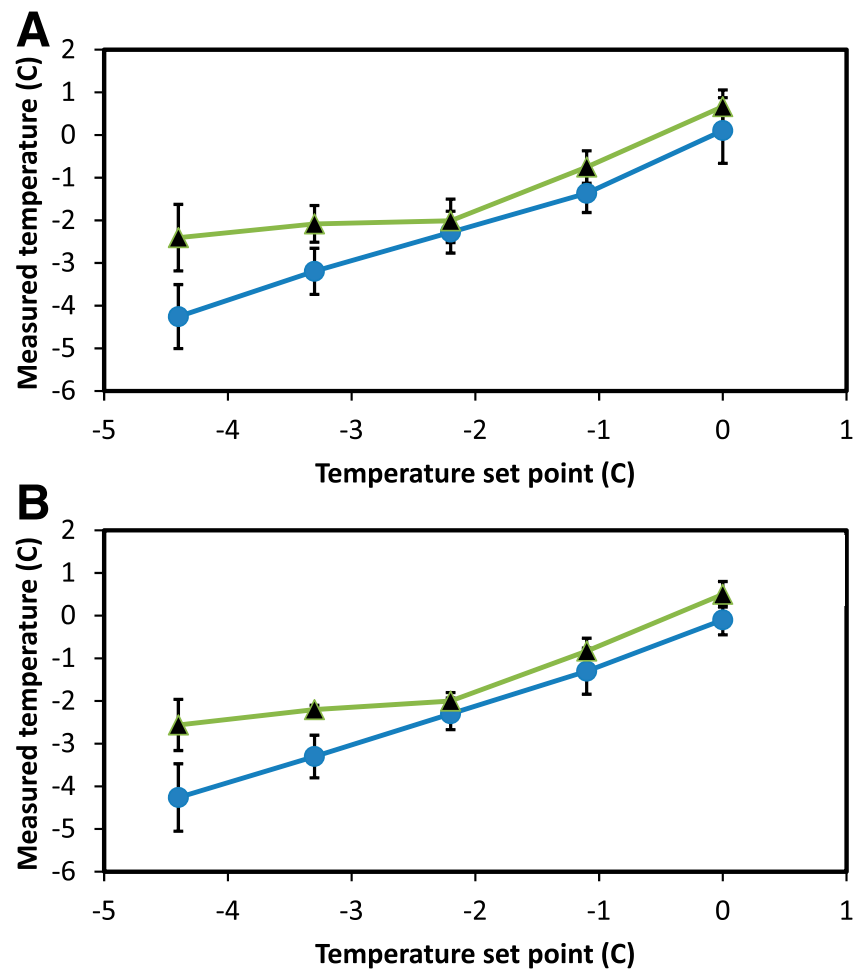

Fig. 1. Air temperature (blue circles) and internal root temperature (black triangles) versus the temperature set points in the refrigerated container during the $\mathbf{A}, 2014$ and B, 2015 studies. 
more $(P \leq 0.01)$ frozen root tissue in both years when roots from the high field were compared with roots from the trace field. With the four BNYVV-resistant cultivars, no frozen tissue differences between roots from high and trace fields existed, except for the two lowest temperatures in 2015 with B-43. At the three higher temperature treatments $\left(0.0,-1.1\right.$, and $\left.-2.2^{\circ} \mathrm{C}\right)$, regardless of cultivar and field, none of the values for frozen tissue differed from 0 .

Discolored root surface. In the 2014 and 2015 studies, there were interactions with the discolored root surface data which led us to analyze the data by temperature and field within each cultivar (Table 2).
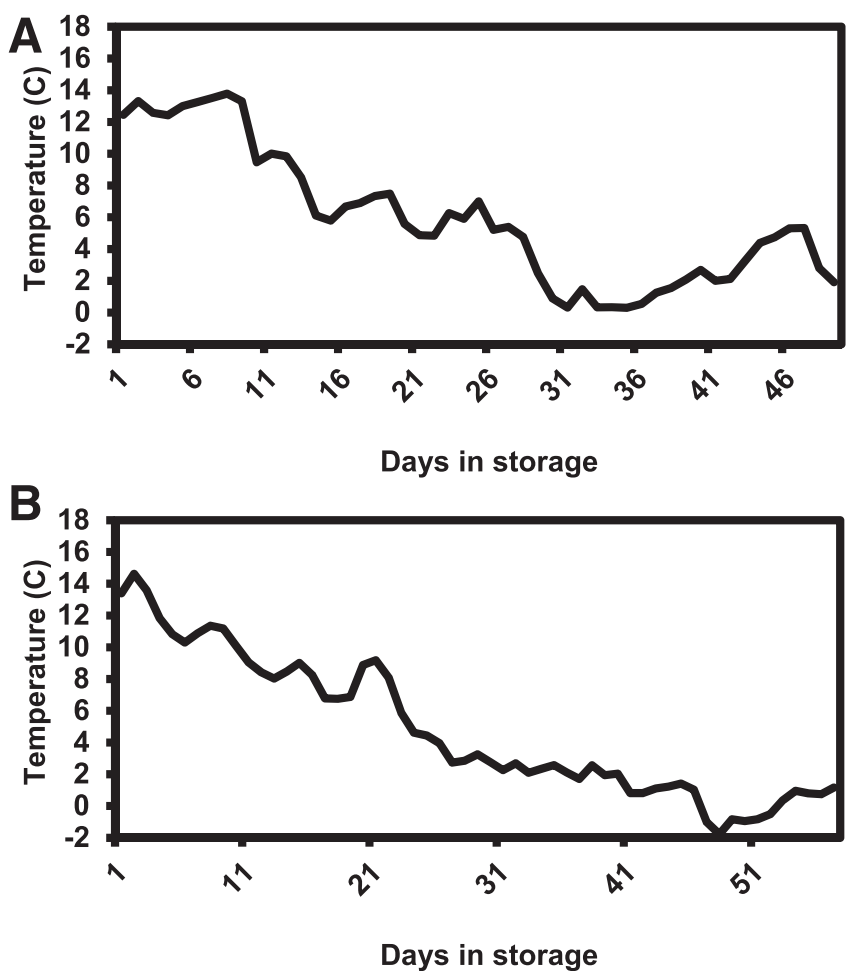

Fig. 2. Average daily temperature $\left({ }^{\circ} \mathrm{C}\right)$ during storage in commercial sugar beet indoor storage facility in Paul, ID A, from 14 October to 2 December (50 days) with 2014 roots and B, from 12 October to 7 December (57 days) with 2015 roots.
The $-4.4^{\circ} \mathrm{C}$ treatment always ranked the worst for the most discolored root surface regardless of cultivar and field. In addition, the $-4.4^{\circ} \mathrm{C}$ treatment was significantly $(P=0.0427$ to $P<0.0001)$ worse than all other treatments in 16 of 20 cultivar-field combinations. With the BNYVV-susceptible B-54, all temperatures in 2015 led to significantly $(P \leq 0.01)$ more discolored root surface with roots from the high field compared with those from the trace field. In 2014, only the two lowest temperatures led to significant $(P \leq$ $0.01)$ differences between fields. With the other four cultivars with some BNYVV resistance, discolored surface differences existed between roots from high and trace fields in only 8 of the 40 cultivarfield combinations over the 2 years. Isolations from discolored tissue indicated that Botrytis cinerea Pers. (in $63 \%$ of samples) was the predominate fungus isolated in 2014, while Phoma betae A. B. Frank, Penicillium spp., Fusarium spp., yeast, and Neonectria spp. were present in $27,13,13,7$, and $3 \%$ of the samples, respectively. More than one fungus was isolated from some samples. In 2015, Penicillium spp. (in $60 \%$ of samples) were the most frequently isolated fungi, while $P$. betae, B. cinerea, Rhizopus spp., and yeast were present in $30,10,10$, and $5 \%$ of the samples, respectively. Discolored tissue was highly correlated $(P<0.0001)$ with frozen tissue $\left(r^{2}=\right.$ 0.91 in 2014 and 2015).

Weight loss. In the 2014 and 2015 studies, there were interactions with the weight loss data which led us to analyze the data by temperature and field within each cultivar (Table 3 ). The $-4.4^{\circ} \mathrm{C}$ treatment ranked the worst for the most weight loss in 13 of 20 cultivar-field combinations over the 2 years. However, the $-4.4^{\circ} \mathrm{C}$ treatment was only significantly $(P<0.0001)$ worse than all other treatments in 2 of 20 cultivar-field combinations. With the BNYVV-susceptible B-54, the high field led to more $(P \leq 0.01)$ weight loss in only 2 of 10 comparisons over the 2 years. Other weight loss comparisons also did not lead to any consistent trends. Weight loss was weakly related $(P<0.0001)$ to frozen tissue $\left(r^{2}=0.28\right.$ and 0.12 in 2014 and 2015 , respectively) and discolored tissue $\left(r^{2}=0.30\right.$ and 0.18 in 2014 and 2015, respectively).

Sucrose reduction. In the 2014 and 2015 studies, there were interactions with the sucrose reduction data which led us to analyze the data by temperature and field within each cultivar (Table 4). The $-4.4^{\circ} \mathrm{C}$ treatment always ranked the worst for the most sucrose lost regardless of cultivar and field. In addition, the $-4.4^{\circ} \mathrm{C}$ treatment was significantly $(P=0.0490$ to $P<0.0001)$ worse than all other treatments in 17 of 20 cultivar-field combinations. With the

Table 1. Percentage of frozen root surface area on roots of five sugar beet cultivars grown in 2014 and 2015 in Idaho fields with high and trace levels of rhizomania and stored at five temperatures $(\mathrm{T})$ ranging from 0 to $-4.4^{\circ} \mathrm{C}^{\mathrm{y}}$

\begin{tabular}{|c|c|c|c|c|c|c|c|c|c|c|}
\hline \multirow[b]{3}{*}{$\mathbf{T}\left({ }^{\circ} \mathbf{C}\right)$} & \multicolumn{10}{|c|}{ Sugar beet cultivars ${ }^{\mathrm{z}}$} \\
\hline & \multicolumn{2}{|c|}{ B-54 $(r z 1 r z 2)$} & \multicolumn{2}{|c|}{ B-7 (Rz1rz2) } & \multicolumn{2}{|c|}{ B-43 $(R z 1 r z 2)$} & \multicolumn{2}{|c|}{ B-46 $(R z 1 R z 2)$} & \multicolumn{2}{|c|}{ B-58 $(R z 1 R z 2)$} \\
\hline & High & Trace & High & Trace & High & Trace & High & Trace & High & Trace \\
\hline \multicolumn{11}{|l|}{2014} \\
\hline 0.0 & $0 \mathrm{~b}$ & $0 \mathrm{~b}$ & $0 \mathrm{~b}$ & $0 \mathrm{~b}$ & $0 \mathrm{~b}$ & $0 \mathrm{~b}$ & $0 \mathrm{~b}$ & $0 \mathrm{~b}$ & $0 \mathrm{~b}$ & $0 \mathrm{~b}$ \\
\hline-1.1 & $2 b$ & $0 \mathrm{~b}$ & $0 \mathrm{~b}$ & $0 \mathrm{~b}$ & $0 \mathrm{~b}$ & $0 \mathrm{~b}$ & $0 \mathrm{~b}$ & $1 \mathrm{~b}$ & $0 \mathrm{~b}$ & $0 \mathrm{~b}$ \\
\hline-2.2 & $3 \mathrm{~b}$ & $0 \mathrm{~b}$ & $0 \mathrm{~b}$ & $1 \mathrm{~b}$ & $0 \mathrm{~b}$ & $0 \mathrm{~b}$ & $0 \mathrm{~b}$ & $0 \mathrm{~b}$ & $0 \mathrm{~b}$ & $0 \mathrm{~b}$ \\
\hline-3.3 & $16 \mathrm{~b}$ & $0 \mathrm{~b}^{* *}$ & $0 \mathrm{~b}$ & $11 \mathrm{ab}$ & $5 \mathrm{~b}$ & $2 \mathrm{~b}$ & $0 \mathrm{~b}$ & $2 \mathrm{~b}$ & $2 b$ & $0 \mathrm{~b}$ \\
\hline-4.4 & $63 \mathrm{a}$ & $13 \mathrm{a}^{* *}$ & $6 \mathrm{a}$ & $24 \mathrm{a}$ & $29 \mathrm{a}$ & $30 \mathrm{a}$ & $10 \mathrm{a}$ & $22 \mathrm{a}$ & $50 \mathrm{a}$ & $77 \mathrm{a}$ \\
\hline$P>F$ & $<0.0001$ & 0.0490 & 0.0132 & 0.0065 & $<0.0001$ & 0.0002 & 0.0003 & 0.0004 & $<0.0001$ & $<0.0001$ \\
\hline \multicolumn{11}{|l|}{2015} \\
\hline 0.0 & $0 \mathrm{c}$ & $0 \mathrm{~b}$ & $0 \mathrm{~b}$ & $0 \mathrm{~b}$ & $0 \mathrm{c}$ & $0 \mathrm{~b}$ & 0 & 0 & 0 & $0 \mathrm{~b}$ \\
\hline-1.1 & $0 \mathrm{c}$ & $0 \mathrm{~b}$ & $0 \mathrm{~b}$ & $0 \mathrm{~b}$ & $0 \mathrm{c}$ & $0 \mathrm{~b}$ & 0 & 0 & 0 & $0 \mathrm{~b}$ \\
\hline-2.2 & $7 \mathrm{c}$ & $0 \mathrm{~b}^{* *}$ & $0 \mathrm{~b}$ & $0 \mathrm{~b}$ & $0 \mathrm{c}$ & $0 \mathrm{~b}$ & 0 & 0 & 0 & $0 \mathrm{~b}$ \\
\hline-3.3 & $63 \mathrm{~b}$ & $0 \mathrm{~b}^{* *}$ & $0 \mathrm{~b}$ & $0 \mathrm{~b}$ & $24 \mathrm{~b}$ & $2 b^{*}$ & 2 & 0 & 7 & $1 \mathrm{~b}$ \\
\hline-4.4 & $90 \mathrm{a}$ & $27 \mathrm{a}^{* *}$ & $39 a$ & $32 \mathrm{a}$ & $60 \mathrm{a}$ & $21 \mathrm{a}^{*}$ & 11 & 14 & 14 & $18 \mathrm{a}$ \\
\hline$P>F$ & $<0.0001$ & 0.0179 & 0.0017 & $<0.0001$ & $<0.0001$ & $<0.0001$ & 0.2991 & 0.4261 & 0.1104 & 0.0240 \\
\hline
\end{tabular}

y $P>F$ was the probability associated with the $F$ value. Data were analyzed in SAS using Proc GLM. When the frozen data were all between 0 and $20 \%$, data were square root transformed prior to analysis. However, untransformed means have been presented in the table. Because of interactions, fields were compared across columns within a cultivar at a specific temperature $(* *$ and $*=$ significant at $P \leq 0.01$ and 0.05 , respectively). Temperatures were compared by field and cultivar within a column. Means within a column were significantly different based on Fisher's protected least significant difference $(\alpha=0.05)$ if letters differed.

${ }^{\mathrm{z}}$ Five commercial sugar beet cultivars containing different combinations of genes (none $=r z 1 r z 2$, one $=R z 1 r z 2$, and two $=R z, 1 R z 2$ ) resistant to Beet necrotic yellow vein virus (BNYVV), the causal agent of rhizomania. High $=98$ to $100 \%$ incidence of BNYVV with a susceptible cultivar and Trace $=$ less than $1 \%$ incidence of BNYVV with a susceptible cultivar. 
BNYVV-susceptible B-54, roots from the high field always lost more $(P \leq 0.01)$ sucrose when compared with the roots from the trace field regardless of temperature and year. A few field comparison differences existed with the resistant cultivars but no consistent trends were evident with temperatures evaluated above $-4.4^{\circ} \mathrm{C}$. Sucrose reduction was related $(P<0.0001)$ to frozen tissue $\left(r^{2}=0.74\right.$ and 0.69 in 2014 and 2015, respectively), discolored tissue ( $r^{2}=0.77$ and 0.75 in 2014 and 2015, respectively), and weight loss ( $r^{2}=0.40$ and 0.19 in 2014 and 2015, respectively).

\section{Discussion}

BNYVV has been shown to negatively influence yield in the field and subsequently also increase sucrose loss in storage (Campbell et al. 2008, Strausbaugh et al. 2008b). This investigation is the first to show that a cultivar susceptible to BNYVV can also suffer more frozen root tissue in storage. The BNYVV-susceptible B-54 had more frozen root tissue with the -3.3 and $-4.4^{\circ} \mathrm{C}$ treatments in both years when comparing roots from the high field with roots from the trace field. With the four BNYVV-resistant cultivars, no frozen tissue differences between roots from high and trace fields existed, except for the two lowest temperatures in 2015 with B-43. Thus, maintaining adequate host resistance to BNYVV is important not only for reducing yield losses in the field and sucrose losses in storage but also for improving storage through decreased susceptibility to freeze damage.

One of the primary means of managing sugar beet roots in storage piles is through temperature control (Bugbee 1993). Cool nighttime air is utilized to cool piles by forcing cool air up through the pile via

Table 2. Percentage of discolored root surface area on roots of five sugar beet cultivars grown in 2014 and 2015 Idaho fields with high and trace levels of rhizomania and stored at temperatures $(\mathrm{T})$ ranging from 0 to $-4.4^{\circ} \mathrm{C}^{\mathrm{y}}$

\begin{tabular}{|c|c|c|c|c|c|c|c|c|c|c|}
\hline \multirow[b]{3}{*}{$\mathbf{T}\left({ }^{\circ} \mathbf{C}\right)$} & \multicolumn{10}{|c|}{ Sugar beet cultivars ${ }^{\mathrm{Z}}$} \\
\hline & \multicolumn{2}{|c|}{ B-54 $(r z 1 r z 2)$} & \multicolumn{2}{|c|}{ B-7 $(R z 1 r z 2)$} & \multicolumn{2}{|c|}{ B-43 $(R z 1 r z 2)$} & \multicolumn{2}{|c|}{ B-46 $(R z 1 R z 2)$} & \multicolumn{2}{|c|}{ B-58 $(R z 1 R z 2)$} \\
\hline & High & Trace & High & Trace & High & Trace & High & Trace & High & Trace \\
\hline \multicolumn{11}{|l|}{2014} \\
\hline 0.0 & $4 \mathrm{c}$ & $2 \mathrm{~b}$ & $4 \mathrm{~b}$ & $8 \mathrm{~b}$ & $5 \mathrm{~b}$ & $3 \mathrm{~b}$ & $2 \mathrm{c}$ & $13 \mathrm{~b}^{* *}$ & $2 b$ & $3 \mathrm{~b}$ \\
\hline-1.1 & $8 \mathrm{c}$ & $4 \mathrm{~b}$ & $5 \mathrm{~b}$ & $8 \mathrm{~b}$ & $7 \mathrm{~b}$ & $3 b$ & $2 \mathrm{c}$ & $14 \mathrm{~b}^{* *}$ & $3 b$ & $3 \mathrm{~b}$ \\
\hline-2.2 & $15 \mathrm{bc}$ & $6 \mathrm{~b}$ & $10 \mathrm{~b}$ & $9 \mathrm{~b}$ & $7 \mathrm{~b}$ & $6 \mathrm{~b}$ & $6 \mathrm{bc}$ & $11 \mathrm{~b}$ & $8 \mathrm{~b}$ & $8 \mathrm{~b}$ \\
\hline-3.3 & $31 \mathrm{~b}$ & $7 b^{* *}$ & $9 \mathrm{~b}$ & $29 \mathrm{a}$ & $18 \mathrm{~b}$ & $7 \mathrm{~b}$ & $12 \mathrm{~b}$ & $10 \mathrm{~b}$ & $10 \mathrm{~b}$ & $8 \mathrm{~b}$ \\
\hline-4.4 & $70 \mathrm{a}$ & $23 \mathrm{a}^{* *}$ & $23 \mathrm{a}$ & $44 \mathrm{a}$ & $41 \mathrm{a}$ & $41 \mathrm{a}$ & $23 \mathrm{a}$ & $37 \mathrm{a}$ & $58 \mathrm{a}$ & $83 \mathrm{a}$ \\
\hline$P>F$ & $<0.0001$ & 0.0427 & 0.0001 & 0.0014 & 0.0002 & 0.0001 & $<0.0001$ & 0.0034 & $<0.0001$ & $<0.0001$ \\
\hline \multicolumn{11}{|l|}{2015} \\
\hline 0.0 & $18 \mathrm{c}$ & $4 \mathrm{~b}^{* *}$ & $6 \mathrm{~b}$ & $6 \mathrm{~b}$ & $20 \mathrm{~b}$ & $11 \mathrm{~b}^{* *}$ & 6 & 5 & 6 & $6 \mathrm{~b}$ \\
\hline-1.1 & $22 \mathrm{c}$ & $6 \mathrm{~b}^{* *}$ & $7 \mathrm{~b}$ & $5 \mathrm{~b}$ & $21 \mathrm{~b}$ & $3 b^{* *}$ & 8 & $3^{*}$ & 8 & $4 b^{*}$ \\
\hline-2.2 & $24 \mathrm{c}$ & $6 b^{* *}$ & $4 \mathrm{~b}$ & $3 \mathrm{~b}$ & $17 \mathrm{~b}$ & $5 b^{*}$ & 7 & 5 & 8 & $3 \mathrm{~b}$ \\
\hline-3.3 & $76 \mathrm{~b}$ & $11 \mathrm{~b}^{* *}$ & $10 \mathrm{~b}$ & $2 \mathrm{~b}$ & $36 \mathrm{~b}$ & $12 \mathrm{~b}$ & 12 & 6 & 19 & $8 \mathrm{~b}$ \\
\hline-4.4 & $95 \mathrm{a}$ & $43 \mathrm{a}^{* *}$ & $47 \mathrm{a}$ & $39 a$ & $70 a$ & $33 \mathrm{a}^{*}$ & 19 & 23 & 27 & $28 \mathrm{a}$ \\
\hline$P>F$ & $<0.0001$ & 0.0015 & 0.0039 & $<0.0001$ & 0.0002 & 0.0003 & 0.3922 & 0.1818 & 0.0720 & 0.0159 \\
\hline
\end{tabular}

y $P>F$ was the probability associated with the $F$ value. Data were analyzed in SAS using Proc GLM. When the frozen data were all between 0 and $20 \%$, data were square root transformed prior to analysis. However, untransformed means have been presented in the table. Because of interactions, fields were compared across columns within a cultivar at a specific temperature (** and $*=$ significant at $P \leq 0.01$ and 0.05 , respectively). Temperatures were compared by field and cultivar within a column. Means within a column were significantly different based on Fisher's protected least significant difference $(\alpha=0.05)$ if letters differed.

${ }^{\mathrm{z}}$ Five commercial sugar beet cultivars containing different combinations of genes (none $=r z 1 r z 2$, one $=R z 1 r z 2$, and two $\left.=R z 1 R z 2\right)$ resistant to Beet necrotic yellow vein virus (BNYVV), the causal agent of rhizomania. High $=98$ to $100 \%$ incidence of BNYVV with a susceptible cultivar and Trace $=$ less than $1 \%$ incidence of BNYVV with a susceptible cultivar.

Table 3. Percentage of root weight loss in roots of five sugar beet cultivars grown in 2014 and 2015 Idaho fields with high and trace levels of rhizomania and stored at temperatures $(\mathrm{T})$ ranging from 0 to $-4.4^{\circ} \mathrm{C}^{\mathrm{y}}$

\begin{tabular}{|c|c|c|c|c|c|c|c|c|c|c|}
\hline \multirow[b]{3}{*}{$\mathbf{T}\left({ }^{\circ} \mathbf{C}\right)$} & \multicolumn{10}{|c|}{ Sugar beet cultivars ${ }^{\mathrm{z}}$} \\
\hline & \multicolumn{2}{|c|}{ B-54 (rz1rz2) } & \multicolumn{2}{|c|}{ B-7 $(R z 1 r z 2)$} & \multicolumn{2}{|c|}{ B-43 $(\operatorname{Rz} 1 r z 2)$} & \multicolumn{2}{|c|}{ B-46 $(R z 1 R z 2)$} & \multicolumn{2}{|c|}{$\mathrm{B}-58(R z 1 R z 2)$} \\
\hline & High & Trace & High & Trace & High & Trace & High & Trace & High & Trace \\
\hline \multicolumn{11}{|l|}{2014} \\
\hline 0.0 & 7.4 & $7.1 \mathrm{c}$ & $7.2 \mathrm{~b}$ & 6.4 & $6.6 \mathrm{~b}$ & $6.2 \mathrm{~b}$ & $6.8 \mathrm{c}$ & $8.8^{*}$ & $7.3 \mathrm{~b}$ & $7.6 \mathrm{~b}$ \\
\hline-1.1 & 8.2 & $7.4 \mathrm{bc}$ & $8.4 \mathrm{ab}$ & 7.5 & $7.9 \mathrm{ab}$ & $6.2 \mathrm{~b}$ & $7.7 \mathrm{bc}$ & $9.4^{*}$ & $8.2 \mathrm{~b}$ & $8.3 \mathrm{~b}$ \\
\hline-2.2 & 8.8 & $7.9 \mathrm{bc}$ & $7.3 \mathrm{~b}$ & 8.1 & $6.7 \mathrm{~b}$ & $6.3 \mathrm{~b}$ & $7.8 \mathrm{bc}$ & 10.2 & $7.6 \mathrm{~b}$ & $8.5 \mathrm{~b}$ \\
\hline-3.3 & 10.5 & $9.6 \mathrm{ab}$ & $9.3 \mathrm{a}$ & 8.2 & $7.9 \mathrm{ab}$ & $7.4 \mathrm{ab}$ & $10.2 \mathrm{a}$ & 10.0 & $9.0 \mathrm{~b}$ & $8.9 \mathrm{~b}$ \\
\hline-4.4 & 10.1 & $10.5 \mathrm{a}$ & $9.7 \mathrm{a}$ & 8.7 & $9.2 \mathrm{a}$ & $9.5 \mathrm{a}$ & $9.3 \mathrm{ab}$ & 9.8 & $14.8 \mathrm{a}$ & $13.7 \mathrm{a}$ \\
\hline$P>F$ & 0.1477 & 0.0285 & 0.0064 & 0.1813 & 0.0069 & 0.0360 & 0.0319 & 0.2245 & $<0.0001$ & $<0.0001$ \\
\hline \multicolumn{11}{|l|}{2015} \\
\hline 0.0 & $9.7 \mathrm{ab}$ & $8.2 \mathrm{ab}$ & $6.5 \mathrm{~b}$ & $9.5 \mathrm{a}$ & $9.5 \mathrm{ab}$ & 8.5 & $10.7 \mathrm{a}$ & $7.3^{*}$ & 7.7 & 6.8 \\
\hline-1.1 & $10.5 \mathrm{a}$ & $6.8 \mathrm{bc}^{* *}$ & $6.7 \mathrm{~b}$ & $7.3 \mathrm{bc}$ & $7.3 \mathrm{~b}$ & 6.5 & $6.3 \mathrm{~b}$ & 7.2 & 8.2 & 6.7 \\
\hline-2.2 & $8.0 \mathrm{~b}$ & $5.7 \mathrm{c}$ & $7.0 \mathrm{~b}$ & $6.0 \mathrm{c}$ & $9.3 \mathrm{~b}$ & 7.2 & $8.7 \mathrm{a}$ & $6.5^{*}$ & 8.7 & $5.8^{*}$ \\
\hline-3.3 & $11.8 \mathrm{a}$ & $6.7 \mathrm{bc} * *$ & $10.2 \mathrm{a}$ & $8.0 \mathrm{ab}$ & $9.0 \mathrm{~b}$ & 7.7 & $8.7 \mathrm{a}$ & 6.0 & 8.3 & 7.2 \\
\hline-4.4 & $10.7 \mathrm{a}$ & $9.3 \mathrm{a}$ & $10.8 \mathrm{a}$ & $7.8 \mathrm{a}-\mathrm{c}^{* *}$ & $11.8 \mathrm{a}$ & $8.8^{*}$ & $9.0 \mathrm{a}$ & 9.0 & 8.3 & 8.0 \\
\hline$P>F$ & 0.0257 & 0.0102 & 0.0006 & 0.0230 & 0.0196 & 0.1892 & 0.0088 & 0.0958 & 0.9109 & 0.3979 \\
\hline
\end{tabular}

y $P>F$ was the probability associated with the $F$ value. Data were analyzed in SAS using Proc GLM. When the frozen data were all between 0 and $20 \%$, data were square root transformed prior to analysis. However, untransformed means have been presented in the table. Because of interactions, fields were compared across columns within a cultivar at a specific temperature (** and $*=$ significant at $P \leq 0.01$ and 0.05 , respectively). Temperatures were compared by field and cultivar within a column. Means within a column were significantly different based on Fisher's protected least significant difference $(\alpha=0.05)$ if letters differed.

${ }^{\mathrm{z}}$ Five commercial sugar beet cultivars containing different combinations of genes (none $=r z 1 r z 2$, one $=R z 1 r z 2$, and two $=R z, 1 R z 2$ ) resistant to Beet necrotic yellow vein virus (BNYVV), the causal agent of rhizomania. High $=98$ to $100 \%$ incidence of BNYVV with a susceptible cultivar and Trace $=$ less than $1 \%$ incidence of BNYVV with a susceptible cultivar. 
Table 4. Percentage of sucrose reduction in roots of five sugar beet cultivars grown in 2014 and 2015 Idaho fields with high and trace levels of rhizomania and stored at temperatures $(\mathrm{T})$ ranging from 0 to $-4.4^{\circ} \mathrm{C}^{\mathrm{y}}$

\begin{tabular}{|c|c|c|c|c|c|c|c|c|c|c|}
\hline \multirow[b]{3}{*}{$\mathbf{T}\left({ }^{\circ} \mathbf{C}\right)$} & \multicolumn{10}{|c|}{ Sugar beet cultivars ${ }^{\mathrm{z}}$} \\
\hline & \multicolumn{2}{|c|}{ B-54 (rz1rz2) } & \multicolumn{2}{|c|}{ B-7 $(R z 1 r z 2)$} & \multicolumn{2}{|c|}{ B-43 $(R z 1 r z 2)$} & \multicolumn{2}{|c|}{ B-46 $(R z 1 R z 2)$} & \multicolumn{2}{|c|}{ B-58 $(R z 1 R z 2)$} \\
\hline & High & Trace & High & Trace & High & Trace & High & Trace & High & Trace \\
\hline \multicolumn{11}{|l|}{2014} \\
\hline 0.0 & $27 \mathrm{c}$ & $16 \mathrm{~b}^{* *}$ & $19 \mathrm{~b}$ & $19 \mathrm{~b}$ & $19 b$ & $17 \mathrm{~b}$ & $15 \mathrm{c}$ & $26 b^{*}$ & $18 \mathrm{~b}$ & $19 \mathrm{~b}$ \\
\hline-1.1 & $31 \mathrm{c}$ & $17 \mathrm{~b}^{* *}$ & $18 \mathrm{~b}$ & $20 \mathrm{~b}$ & $16 \mathrm{~b}$ & $16 \mathrm{~b}$ & $16 \mathrm{c}$ & $30 \mathrm{~b}^{* *}$ & $17 \mathrm{~b}$ & $17 \mathrm{~b}$ \\
\hline-2.2 & $39 \mathrm{bc}$ & $16 \mathrm{~b}^{* *}$ & $23 \mathrm{~b}$ & $23 \mathrm{~b}$ & $24 \mathrm{~b}$ & $16 \mathrm{~b}$ & $16 \mathrm{c}$ & $32 \mathrm{~b}^{* *}$ & $16 \mathrm{~b}$ & $19 \mathrm{~b}$ \\
\hline-3.3 & $50 \mathrm{~b}$ & $20 \mathrm{~b}^{* *}$ & $22 \mathrm{~b}$ & $27 \mathrm{~b}$ & $26 \mathrm{~b}$ & $19 \mathrm{~b}$ & $22 \mathrm{~b}$ & $26 \mathrm{~b}$ & $18 \mathrm{~b}$ & $23 \mathrm{~b}$ \\
\hline-4.4 & $67 \mathrm{a}$ & $30 \mathrm{a}^{* *}$ & $35 \mathrm{a}$ & $44 \mathrm{a}$ & $43 \mathrm{a}$ & $47 \mathrm{a}$ & $42 \mathrm{a}$ & $45 \mathrm{a}$ & $71 \mathrm{a}$ & $79 \mathrm{a}$ \\
\hline$P>F$ & 0.0003 & 0.0016 & $<0.0001$ & 0.0155 & 0.0022 & 0.0001 & $<0.0001$ & 0.0123 & $<0.0001$ & $<0.0001$ \\
\hline \multicolumn{11}{|l|}{2015} \\
\hline 0.0 & $37 \mathrm{c}$ & $20 \mathrm{~b}^{* *}$ & $18 \mathrm{~b}$ & $16 \mathrm{~b}$ & $26 \mathrm{bc}$ & $19 \mathrm{~b}^{*}$ & $15 \mathrm{~b}$ & 12 & $15 \mathrm{c}$ & 13 \\
\hline-1.1 & $40 \mathrm{c}$ & $16 \mathrm{bc} * *$ & $13 \mathrm{~b}$ & $14 \mathrm{bc}$ & $27 \mathrm{bc}$ & $12 \mathrm{~b}^{* *}$ & $13 \mathrm{~b}$ & 14 & $14 \mathrm{c}$ & 13 \\
\hline-2.2 & $32 \mathrm{c}$ & $14 \mathrm{c}^{* *}$ & $20 \mathrm{~b}$ & $10 \mathrm{bc} * *$ & $18 \mathrm{c}$ & $15 \mathrm{~b}$ & $13 \mathrm{~b}$ & 14 & $18 \mathrm{bc}$ & 14 \\
\hline-3.3 & $65 \mathrm{~b}$ & $16 \mathrm{bc} * *$ & $19 \mathrm{~b}$ & $8 c^{* *}$ & $40 \mathrm{~b}$ & $19 \mathrm{ab}^{*}$ & $15 \mathrm{~b}$ & 14 & $25 \mathrm{ab}$ & $12 * *$ \\
\hline-4.4 & $87 \mathrm{a}$ & $25 \mathrm{a}^{* *}$ & $50 \mathrm{a}$ & $40 \mathrm{a}$ & $62 \mathrm{a}$ & $25 \mathrm{a}^{* *}$ & $31 \mathrm{a}$ & 17 & $28 \mathrm{a}$ & 20 \\
\hline$P>F$ & $<0.0001$ & $<0.0001$ & 0.0051 & $<0.0001$ & 0.0006 & 0.0135 & 0.0236 & 0.3415 & 0.0191 & 0.2282 \\
\hline
\end{tabular}

y $P>F$ was the probability associated with the $F$ value. Data were analyzed in SAS using Proc GLM. When the frozen data were all between 0 and $20 \%$, data were square root transformed prior to analysis. However, untransformed means have been presented in the table. Because of interactions, fields were compared across columns within a cultivar at a specific temperature $(* *$ and $*=$ significant at $P \leq 0.01$ and 0.05 , respectively). Temperatures were compared by field and cultivar within a column. Means within a column were significantly different based on Fisher's protected least significant difference $(\alpha=0.05)$ if letters differed.

${ }^{\mathrm{z}}$ Five commercial sugar beet cultivars containing different combinations of genes (none $=r z 1 r z 2$, one $=R z 1 r z 2$, and two $=R z 1 R z 2$ ) resistant to Beet necrotic yellow vein virus (BNYVV), the causal agent of rhizomania. High $=98$ to $100 \%$ incidence of BNYVV with a susceptible cultivar and Trace $=$ less than $1 \%$ incidence of BNYVV with a susceptible cultivar.

ventilation pipes at the bottom. If the ambient air is too cold, the roots can become frozen, which becomes a serious problem if roots cannot be maintained below freezing (Buczys 2007). In the Red River Valley of Minnesota and North Dakota, freezing roots with cold air in early December is a common practice, because the roots can be maintained at temperatures below freezing (Bernhardson 2009; Bugbee 1993). Sugar beet roots have been reported to freeze around -2 to $-3^{\circ} \mathrm{C}$ (Huijbregts et al. 2013; Oldfield et al. 1971; Wyse 1978), which is supported by the data in Figure 1. In other U.S. sugar beet production areas, the freezing of root tissue is a serious problem leading to millions of dollars in losses, because ambient temperatures are not cool enough to maintain below-freezing temperatures (Bugbee 1982; Bugbee and Cole 1976; Huff 2013; Shore et al. 1983; Van Driessche 2012). Once roots in a pile begin thawing, these roots need to be processed within days; however, processing these roots can still be problematic because of rapid sugar inversion and gum formation (Buczys 2007; de Bruijn 2000; Kenter and Hoffman 2006; Oldfield et al. 1971). Therefore, in an effort to improve pile management, data from the 2014-15 storage studies help define the lower limits for air temperature when cooling a pile. In both years, the internal root temperature remained constant and deviated from ambient air temperature at temperatures below $-2.2{ }^{\circ} \mathrm{C}$ (Fig. 1). Oldfield et al. (1971) showed that the internal root temperature could be maintained at $-2^{\circ} \mathrm{C}$ for a few hours when ambient temperature was -11 to $-13^{\circ} \mathrm{C}$. Our data add to this observation to show that this relationship will hold for up to several days when ambient temperatures are between -2.2 and $-4.4^{\circ} \mathrm{C}$ (Fig. 1). Previous research with root disks and the release of carbohydrates suggested that cell damage can become extensive at $-2^{\circ} \mathrm{C}$ and, by $-3^{\circ} \mathrm{C}$, half the cells can become damaged (Wyse 1978). Therefore, the results from these studies suggest that sucrose losses and ruptured cell membranes can be reduced by cooling piles with ambient air above $-2^{\circ} \mathrm{C}$.

When developing winter sugar beet, researchers noted that certain compounds such as sucrose, betaine, and glutamine tend to accumulate in relation to survival rate (Loel and Hoffman 2015). In both years in the present study, sucrose loss was strongly related $\left(r^{2}=\right.$ 0.74 and 0.69 in 2014 and 2015, respectively, with $P<0.0001$ ) to the amount of frozen tissue in sugar beet roots. These results mirror those found with winter sugar beet.

Rot in sugar beet root piles is also a major concern and can result in major financial losses (Bugbee 1982; Bugbee and Cole 1976; Huff
2013; Van Driessche 2012). The discolored (rotted or water soaked) tissue in this study was the variable most strongly related $\left(r^{2}=0.91\right.$ in both years) to frozen tissue. This close relationship likely occurred because most of the discolored tissue was frozen tissue. The reason for placing the temperature-treated roots into standard storage for at least 50 days was to make it easy to determine what tissue may have recovered from the cold temperatures. The damage to cell membranes caused by freezing is reversible within limits, depending on thawing conditions (Barbier et al. 1982). After approximately 50 days in storage, water-soaked and rotting tissues were easy to spot. The primary fungi isolated from the discolored tissue in both years were B. cinerea, $P$. betae, and Penicillium spp. (Penicillium expansum Link and $P$. cellarum C. A. Strausb. \& Dugan). These three fungal genera have commonly been reported to be associated with sugar root tissue in previous investigations with unfrozen sugar beet roots (Bugbee 1982, 1993; Bugbee and Cole 1976; Fugate and Campbell 2009; Liebe and Varrelmann 2016; Strausbaugh and Dugan 2017; Strausbaugh et al. 2015). Consequently, the fungi isolated from the rotted tissue were typical of what would be expected even without the involvement of frozen tissue.

Sucrose reduction is the primary concern in sugar beet storage. In this study, the $-4.4^{\circ} \mathrm{C}$ treatment always ranked the worst for sucrose loss regardless of cultivar and field and led to significantly more sucrose reduction in 17 of 20 cultivar-field combinations. These data help emphasize that air used to cool sugar beet roots in storage piles should not be below $-2.2^{\circ} \mathrm{C}$ to maximize sucrose retention, if roots are to be stored unfrozen. With BNYVV-resistant cultivars, there were no consistent trends evident for sucrose retention with temperatures above $-4.4^{\circ} \mathrm{C}$. The data from this study help emphasize that maintaining good host resistance to BNYVV is critical for maximizing sucrose yields not only in the field but also in storage. When good host resistance to BNYVV is combined with proper temperature control in sugar beet storage piles, less sucrose will be lost.

\section{Acknowledgments}

These data support the objectives for the United States Department of Agriculture Current Research Information System project 5368-21220-003-00D. We thank the Amalgamated Sugar Co., LLC; Amalgamated Research, LLC; Beet Sugar Development Foundation; and Snake River sugar beet growers for supporting our research work; and J. Reed, D. Kenney, and T. Keeth for their technical support efforts. 


\section{Literature Cited}

Acosta-Leal, R., Fawley, M. W., and Rush, C. M. 2008. Changes in the intraisolate genetic structure of Beet necrotic yellow vein virus populations associated with plant resistance breakdown. Virology 376:60-68.

Barbier, H., Nalin, F., and Guern, J. 1982. Freezing injury in sugar beet root cells: Sucrose leakage and modifications of tonoplast properties. Plant Sci. Lett. 26:75-81. Bernhardson, D. 2009. Sugarbeet storage techniques developed. Int. Sugar J. 111: 628-631.

Biancardi, E., Lewellen, R. T., de Biaggi, M., Erichsen, A. W., and Stevanato, P. 2002. The origin of rhizomania resistance in sugar beet. Euphytica 127:383-397.

Bornemann, K., and Varrelmann, M. 2011. Analysis of the resistance-breaking ability of different Beet necrotic yellow vein virus isolates loaded into a single Polymyxa betae population in soil. Phytopathology 101:718-724.

Bornemann, K., and Varrelmann, M. 2013. Effect of sugar beet genotype on the Beet necrotic yellow vein virus $\mathrm{P} 25$ pathogenicity factor and evidence for a fitness penalty in resistance-breaking strains. Mol. Plant Pathol. 14:356-364.

Buczys, R. 2007. Processing beet affected by frost damage. Sugar Ind. 132: 741-746.

Bugbee, W. M. 1982. Storage rot of sugar beet. Plant Dis. 66:871-873.

Bugbee, W. M. 1993. Storage. Pages 551-570 in: The Sugar Beet Crop: Science into Practice. D. A. Cooke and R. K. Scott, eds. Chapman and Hall, London.

Bugbee, W. M., and Cole, D. F. 1976. Sugarbeet storage rot in the Red River Valley 1974-75. J. Am. Soc. Sugar Beet Technol. 19:19-24.

Campbell, L. G., Fugate, K. K., and Niehaus, W. S. 2011. Fusarium yellows affects postharvest respiration rate, sucrose concentration, and invert sugar in sugarbeet. J. Sugar Beet Res. 48:17-39.

Campbell, L. G., and Klotz, K. L. 2006. Postharvest storage losses associated with Aphanomyces root rot in sugarbeet. J. Sugar Beet Res. 43:113-128.

Campbell, L. G., Klotz, K. L., and Smith, L. J. 2008. Postharvest storage losses associated with rhizomania in sugar beet. Plant Dis. 92:575-580.

de Bruijn, J. M. 2000. Processing of frost-damaged beets at CSM and the use of dextranase. Sugar Ind. 125:898-902.

Fugate, K., and Campbell, L. 2009. Postharvest deterioration of sugar beet. Pages 92-94 in: Compendium of Beet Diseases and Pests, 2nd ed. R. M. Harveson, L. E. Hanson, and G. Hein, eds. American Phytopathological Society, St. Paul, MN.

Gidner, S., Lennefors, B.-L., Nilsson, N.-O., Bensefelt, J., Johansson, E., Gyllenspetz, U., and Kraft, T. 2005. QTL mapping of BNYVV resistance from the WB41 source in sugar beet. Genome 48:279-285.

Grimmer, M. K., Kraft, T., Francis, S. A., and Asher, M. J. C. 2008. QTL mapping of BNYVV resistance from the WB258 source in sugar beet. Plant Breed. 127: 650-652.

Grimmer, M. K., Trybush, S., Hanley, S., Francis, S. A., Karp, A., and Asher, M. J. C. 2007. An anchored linkage map for sugar beet based on AFLP, SNP and RAPD markers and QTL mapping of a new source of resistance to Beet necrotic yellow vein virus. Theor. Appl. Genet. 114:1151-1160.

Huff, J. 2013. The hidden cost of beet storage. Sugarbeet 2013 Harvest Issue:3-4.

Huijbregts, T., Legrand, G., Hoffman, C., Olsson, R., and Olsson, Å. 2013. Longterm storage of sugar beet in North-West Europe. Coord. Beet Res. Int. Rep. No. 1. Goltze Druck GmbH \& Co. KG, Göttingen, Germany.

Kenter, C., and Hoffman, C. 2006. Changes in the quality of frost-damaged sugarbeet during storage as affected by temperature and variety. Sugar Ind. 131:85-91.

Klotz, K. L., and Campbell, L. G. 2009. Effects of Aphanomyces root rot on carbohydrate impurities and sucrose extractability in postharvest sugar beet. Plant Dis. 93:94-99.
Liebe, S., and Varrelmann, M. 2016. Effect of environment and sugar beet genotype on root rot development and pathogen profile during storage. Phytopathology 106:65-75.

Liu, H.-Y., and Lewellen, R. T. 2007. Distribution and molecular characterization of resistance-breaking isolates of Beet necrotic yellow vein virus in the United States. Plant Dis. 91:847-851.

Liu, H.-Y., Sears, J. L., and Lewellen, R. T. 2005. Occurrence of resistancebreaking Beet necrotic yellow vein virus of sugar beet. Plant Dis. 89:464-468.

Loel, J., and Hoffman, C. M. 2015. Relevance of osmotic and frost protecting compounds for winter hardiness of autumn sown sugar beet. J. Agron. Crop Sci. 201:301-311.

Oldfield, J. F. T., Dutton, J. V., and Teague, H. J. 1971. The significance of invert and gum formation in deteriorated beet. Int. Sugar J. 73:3-8.

Panella, L., and Strausbaugh, C. A. 2017. Evaluation of Ft. Collins sugar beet germplasm for rhizomania and storage rot resistance in Idaho, 2016. Plant Dis. Manage. Rep. 11:FC101.

Peterson, C. L., Hall, M. C., and Traveller, D. J. 1984. Sugarbeet Storage Experiments. ASAE Pap. No. 84-4040. ASAE, Knoxville, TN.

Rush, C. M. 2003. Ecology and epidemiology of Benyviruses and plasmodiophorid vectors. Annu. Rev. Phytopathol. 41:567-592.

Rush, C. M., Liu, H.-Y., Lewellen, R. T., and Acosta-Leal, R. 2006. The continuing saga of rhizomania of sugar beets in the United States. Plant Dis. 90:4-15.

Scholten, O. E., De Bock, T., Klein-Lankhorst, R. M., and Large, W. 1999. Inheritance of resistance to Beet necrotic yellow vein virus in Beta vulgaris conferred by a second gene for resistance. Theor. Appl. Genet. 99:740-746.

Shore, M., Dutton, J. V., and Houghton, B. J. 1983. Evaluation of deteriorated beet. Int. Sugar J. 85:106-110.

Smith, G. A., and Ruppel, E. G. 1971. Cercospora leaf spot as a predisposing factor in storage rot of sugar beet roots. Phytopathology 61:1485-1487.

Strausbaugh, C. A., and Dugan, F. 2017. A novel Penicillium sp. causes rot in stored sugar beet roots in Idaho. Plant Dis. 101:1781-1787.

Strausbaugh, C. A., Eujayl, I. A., Rearick, E., Foote, P., and Elison, D. 2009. Sugar beet cultivar evaluation for storability and rhizomania resistance. Plant Dis. 93: 632-638.

Strausbaugh, C. A., Neher, O., Rearick, E., and Eujayl, I. A. 2015. Influence of harvest timing, fungicides, and Beet necrotic yellow vein virus on sugar beet storage. Plant Dis. 99:1296-1309.

Strausbaugh, C. A., Rearick, E., and Camp, S. 2008a. Influence of curly top and Poncho Beta on storability of sugarbeet. J. Sugar Beet Res. 45:31-47.

Strausbaugh, C. A., Rearick, E., Camp, S., Gallian, J. J., and Dyer, A. T. 2008b. Influence of Beet necrotic yellow vein virus on sugar beet storability. Plant Dis. 92:581-587.

Strausbaugh, C. A., Rearick, E., Eujayl, I. A., and Foote, P. 2011. Influence of Rhizoctonia-bacterial root rot complex on storability of sugarbeet. J. Sugar Beet Res. 48:155-180.

Van Driessche, R. 2012. Michigan sugar company “Ten years of progress”. Sugar Prod. March 2012:21.

Van Eerd, L. L., Congreves, K. A., and Zandstra, J. W. 2012. Sugar beet (Beta vulgaris L.) storage quality in large outdoor piles is impacted by pile management but not by nitrogen fertilizer or cultivar. Can. J. Plant Sci. 92:129-139.

Ward, L., Koenig, R., Budge, G., Garrido, C., McGrath, C., Stubbley, H., and Boonham, N. 2007. Occurrence of two different types of RNA-5-containing beet necrotic yellow vein virus in the U.K. Arch. Virol. 152:59-73.

Wyse, R. 1978. Effect of Low and fluctuating temperatures on storage life of sugarbeets. J. Am. Soc. Sugar Beet Technol. 20:33-42. 